\title{
C-Peptide and cardiovascular risk factors among young adults in a southern Brazilian cohort
}

\author{
Romildo Luiz Monteiro Andrade ${ }^{1,2,3^{*}}$ (D) Denise P. Gigante ${ }^{2}$, Isabel Oliveira de Oliveira² and Bernardo Lessa Horta ${ }^{2}$
}

\begin{abstract}
Background: Proinsulin connecting peptide (C-Peptide) is a marker of the beta-cell function and has been considered a marker of insulin resistance whose evidence suggests were associated with cardiovascular mortality. Our study aims to evaluate the association of C-Peptide with metabolic cardiovascular risk factors among young adults followed since birth in southern Brazil.

Methods: In 1982, maternity hospital in Pelotas, a southern Brazilian city, were visited daily and all births were identified. Live births whose family lived in the urban area of the city were identified, their mothers interviewed, and these subjects have been prospectively followed. Casual hyperglycemia patients were excluded from analysis. C-Peptide was assessed at 23 years, when transversely analyzed its association with cardiometabolic and hemodynamic risk factors, and longitudinally 30 years of age.

Results: At age 23, 4297 individuals were evaluated, and C-Peptide was measured in 3.807. In a cross-sectional analysis at 23 years of age, C-Peptide was positively associated with waist circumference, body mass index, glycaemia, triglycerides, and C-reactive protein. The association with HDL cholesterol was negative. In the longitudinal analysis at 30 years, C-Peptide remained associated with BMI, waist circumference, glycated hemoglobin, triglycerides, and C-reactive protein, whereas the association was negative for HDL.

Conclusion: In the Pelotas birth cohort, the C-Peptide was associated with obesity indicators (waist circumference and BMI) cross-sectional (23 years) and longitudinal (30 years). We also observed cross-sectional and longitudinal associations of C-Peptide with cardiometabolic and inflammatory risk factors.
\end{abstract}

Keywords: C-Peptide, Cardiovascular disease, Risk, Young adults

\section{Background}

In 2012, cardiovascular diseases were the main cause of death, accounting for 17.5 million deaths [1]. And three quarters of these deaths, occurred in low and medium-income countries $(70 \%$ of the global population) [2]. In face of population ageing and the increase in the prevalence of diabetes and obesity, cardiovascular mortality is estimated to rise over the next decades [3, 4].

\footnotetext{
* Correspondence: rlmandrade@hotmail.com

${ }^{1}$ University Hospital Cassiano Antônio de Moraes (HUCAM) of the Federal,

University of Espírito Santo (UFES), Vitória-ES, Brazil

${ }^{2}$ Post-Graduate Program in Epidemiology, Federal University of Pelotas

(UFPel), Pelotas-RS, Brazil

Full list of author information is available at the end of the article
}

Proinsulin connecting peptide-(C-Peptide) is considered a marker of insulin resistance, epidemiological studies suggest its performance as a cardiovascular risk factor [5-7]. Secreted by $\beta$ cells in the pancreas at amounts equimolar to insulin [8], C-Peptide is also a marker of beta cell function, and studies have shown its association to overall cardiovascular risk and mortality [9]. Its pathophysiological activity would be linked to the stimulation of vascular permeability to monocytes, stimulating the differentiation in macrophages, promoting the phagocytosis of molecules of oxidized lipoproteins, such as low-density lipoprotein (LDL), and differentiating into foam cells, the classic cellular substrate of atherosclerotic lesions [10]. C-Peptide would also act in subsequent phases of the atherogenic process,

(C) The Author(s). 2018 Open Access This article is distributed under the terms of the Creative Commons Attribution 4.0 International License (http://creativecommons.org/licenses/by/4.0/), which permits unrestricted use, distribution, and 
inducing the proliferation of smooth muscle cells and the cascade of release of pro-atherogenic components such as cytokines, metalloproteinases, and oxidative molecules, besides clotting factors such as the tissue plasminogen activator (tPA) [11, 12].

Population studies are in line with findings such as Cabrera et al. observed that individuals in the upper tercile of C-Peptide were at higher risk of coronary artery disease (RR 2.4; CI 95\% 1.3-4.6) and myocardial infarction (RR 2.8; C I95\% 1.1-6.9) [13]. Marx et al. reported that serum levels of C-Peptide in patients subjected to coronary angiography were associated with overall (HR 1.46 CI95\% 1.15-1.85) and cardiovascular (HR 1.58 CI 95\% 1.15-2.18) mortality [14]. Patel et al. evaluated individuals with fasting glycaemia $\geq 70 \mathrm{mg} / \mathrm{dL}$ and found that C-Peptide was associated with cardiovascular (HR 1.60, CI95\% 1.07-2.39) and overall (HR 1.72, CI95\% 1.342.21) mortality [15]. Min et al. also found an association with cardiovascular (HR 3.20 CI95\% 2.07-4.93) and overall (HR 1.80 CI95\% 1.33-2.43) mortality.

On the other hand, Bo et al. found no association between C-Peptide and cardiovascular mortality after adjusting for age, sex, body mass index, smoking, time on insulin therapy, glycated hemoglobin, systolic blood pressure, HDL cholesterol, triglycerides, and previous vascular complications [16]. However, the control for other metabolic cardiovascular risk factors may have blocked causal pathways between C-Peptide and mortality, underestimating the association.

Given the small number of studies assessing the association of C-Peptide with metabolic cardiovascular risk factors, and the possibility of analyzing their relation to the long period of follow-up we considered important to investigate such association. The present study aimed to evaluate the cardio-metabolic risk profiles in non-diabetic young stratified according to $\mathrm{C}$-peptide quartiles in a southern Brazilian cohort [7].

\section{Methods}

In 1982, the maternity hospital in Pelotas, a southern Brazilian city, were visited daily and all births were identified. The neonates whose families lived in the urban area were examined and the mothers interviewed soon after birth ( $\mathrm{n}$ 5914). These individuals have been prospectively followed at different moments of their life cycles.

In 2004, an attempt was made to locate all participants of the cohort, using multiple strategies. The subjects were interviewed at home and invited to visit the research laboratory to donate a blood sample [17]. At 30 ages, a new attempt was made to locate all cohort members, who were invited to visit the research clinic, where they were interviewed, examined, and blood samples were collected [18].
Anthropometric variables of weight, was measured at 23 years, using Seca (Uniscale ${ }^{\circ}$, Germany) portable electronic scales with $100 \mathrm{~g}$ precision. Aluminum anthropometers with $1 \mathrm{~mm}$ precision were used to measure height according to Lohman et al. [19]. At 30 years, weight was measured with a scale connected to Bod Pod (Cosmed $^{\circ}$, USA) device and height with an aluminum vertical stadiometer with $1 \mathrm{~mm}$ precision. Waist circumference was measured while the subjects were standing upright with feet together and arms relaxed along the body. The measuring tape was extended on the horizontal plane at waist height (narrowest portion of the trunk) between the last rib and the iliac crest at the end of a regular exhaling and without compressing the skin, and the value was recorded with $0.1 \mathrm{~cm}$ precision. Body mass index (BMI) was calculated by dividing the weight in kilograms $(\mathrm{kg})$ by the square of the height in meters $(\mathrm{m})$.

Cardiometabolic variables were measured at 23 years: capillary glycaemia $(\mathrm{mg} / \mathrm{dL})$, total cholesterol $(\mathrm{mg} / \mathrm{dL})$, HDL cholesterol (mg/dL), triglycerides $(\mathrm{mg} / \mathrm{dL})$, C-reactive protein $(\mathrm{mg} / \mathrm{dL})$. At age 30 , serum glycaemia $(\mathrm{mg} / \mathrm{dL})$, total cholesterol $(\mathrm{mg} / \mathrm{dL}) ; \mathrm{HDL}$ cholesterol $(\mathrm{mg} / \mathrm{dL})$; LDL cholesterol $(\mathrm{mg} / \mathrm{dL})$, triglycerides $(\mathrm{mg} /$ $\mathrm{dL})$; C-reactive protein $(\mathrm{mg} / \mathrm{dL})$; glycated hemoglobin (\%) were measured. At 23 years, glycaemia was measured using an Accu-Chek Advantage (Roche ${ }^{\circ}$ ) portable glucometer, total cholesterol, HDL, and triglycerides were measured using a Selectra 2 (Merck ${ }^{\circ}$, Darmstadt, Germany. C-Peptide was measured in the blood samples collected at 23 years, using the chemiluminescence technique (Immulite - Siemens) [20], because the analyses were performed on samples collected at random, the estimates were adjusted for fasting time.

At 30 years, serum glucose was measured using the colorimetric enzyme assay with K082 -Glicose Monoreagente kits (Bioclin', Brazil), LDL cholesterol was measured with K088 (Bioclin ${ }^{\circ}$, Brazil) kits and glycated hemoglobin (HbA1c), with K09 -HbA1c Bi-reagent (Bio-Rad ${ }^{\circ}$, Berkeley, California, USA) kits. High-sensitivity C-reactive protein (Hs-CRP) was measured using the automated turbidimetry technique with a BS 380 (Shenzhen-Mindray Bio-Medical Electronics Co.; Ltd ${ }^{\ominus}$, China) chemical analyzer. Those measures with values below the lower limit of detection of $0.1 \mathrm{mg} / \mathrm{L}$ were converted to $0.05 \mathrm{mg} /$ L. Expressing acute inflammatory conditions, we excluded values above $10 \mathrm{mg} / \mathrm{L}$ [21]. We also excluded those subjects whose serum glucose level was $>200 \mathrm{mg} / \mathrm{dL}$ at 23 and 30 years due to diabetes mellitus [22].

Blood pressure was measured at 23 years, using an Omron ${ }^{\circ}$ wrist monitor at the beginning and at the end of the interview, about $60 \mathrm{~min}$ apart, with the respondent sited with the arm on a support. At 30 years, blood pressure was measured twice with an HEM705 CPINT $\left(\mathrm{Omron}^{\circ}\right)$ automated device coupled to an arm cuff, which 
was replaced by a proper model for obese subjects. The mean of two measurements was used in the analyses.

The following variables were considered as confounding factors: physical activity was measured at 23 and 30 years of age using the International Physical Activity Questionnaire (IPAQ) [23] maternal skin color (assessed by the interviewer in the perinatal study), monthly family income in minimum wage, tobacco use (those subjects who reported smoking at least one cigarette a day at 23 years were considered as smokers), alcohol consumption (daily intake in $\mathrm{mg} / \mathrm{L}$ ), family history of hypertension (father and/or mother), birthweight (grams), and rapid weight gain between 2 and 4 years (change in $\mathrm{Z}$ score above 0.67 standard deviation) [24] . Paternal and maternal history of dyslipidemia, hypertension, myocardial infarction, and/or stroke was also considered.

The means of the variables according to the quartiles of Pep-C were evaluated according to the trend tests of the ordered groups. Due to the asymmetric distribution, $\mathrm{C}$-reactive protein and triglycerides were transformed into logarithm. Multiple linear regression was used to evaluate the association between C-Peptide and cardiovascular risk factors, estimates were adjusted for confounding variables like: fasting time (estimated as the time between the last meal and blood sample collection), physical activity practice per week (minutes), family income, mother's skin color, birthweight, rapid growth between 2 and 4 years old, smoking at 23 years, alcohol consumption, family history of dyslipidemia, arterial hypertension and stroke, myocardial infarction [23].

The analyses were carried out using the software STATA version 13.1. The study was approved by the Research Ethics Committee of the Medical School of the Federal University of Pelotas under protocol OF. 16/12. All interviews and blood collections were performed after written consent was obtained from the participants.

\section{Results}

In 2004, 4297 individuals were interviewed, which added to the 282 deaths identified in the cohort - represented a follow-up rate of $77.4 \%$. In 2012, 3701 individuals were interviewed, which - given the 325 deaths identified in the cohort - represented a follow-up rate of $68.1 \%$.

In ad-doc tests in the regression models, sex was not shown an interaction condition with the Pep-C values, because of these findings, the analyzes were not stratified between sex. The exclusion criteria used for Hs-CRP greater than $10 \mathrm{mg} / \mathrm{L}$ withdraw participants and the hyperglycemia in the casual glucose dosage ( $>200 \mathrm{mg} / \mathrm{dL}$ ), totaling the exclusion of 02 individuals at the $23^{\mathrm{a}}$ and 25 participants at $30^{\text {a }}$. Table 1 shows the distribution of the studied

Table 1 Participant characteristics at 23 and 30 years old

\begin{tabular}{|c|c|c|c|c|}
\hline \multirow[t]{2}{*}{ Variables } & \multicolumn{2}{|c|}{23 years } & \multicolumn{2}{|c|}{30 years } \\
\hline & $\mathrm{n}$ & $\mu(\mathrm{C} \mid 95 \%)$ & $n$ & $\mu(\mathrm{C} \mid 95 \%)$ \\
\hline \multicolumn{5}{|l|}{ Anthropometric } \\
\hline Weight (kg) & 4263 & $67.0(66.6 ; 67.46)$ & 3525 & $75.6(75.0 ; 76.2)$ \\
\hline Height (cm) & 4263 & $167.4(167.1 ; 167.7)$ & 3581 & $167.7(167.4 ; 168.0)$ \\
\hline Waist circumference (cm) & 4260 & $78.2(77.9 ; 78.5)$ & 3540 & $84.7(84.3 ; 85.1)$ \\
\hline Body mass index & 4136 & $23.6(23.4 ; 23.7)$ & 3508 & $26.8(26.6 ; 27.0)$ \\
\hline \multicolumn{5}{|l|}{ Metabolic } \\
\hline Serum glycaemia (mg/dL) & 3713 & $97.1(96.6 ; 97.6)$ & 3506 & $87.9(87.4 ; 88.4)$ \\
\hline Total cholesterol (mg/dL) & 2417 & $155.9(154.4 ; 157.3)$ & 3506 & $190.6(189.4 ; 191.8)$ \\
\hline HDL cholesterol (mg/dL) & 3801 & $55.5(55.0 ; 55.9)$ & 3506 & $58.7(58.2 ; 59.1)$ \\
\hline LDL cholesterol (mg/dL) & & & 3506 & $109.4(108.4 ; 118.1)$ \\
\hline Triglycerides ${ }^{a}$ (mg/dL) & 3801 & $88.4(86.9 ; 89.9)$ & 3506 & $100.4(98.5 ; 102.2)$ \\
\hline C-reactive protein $(\mathrm{mg} / \mathrm{dL}) \#$ & 3449 & $2.0(2.0 ; 2.1)$ & 3188 & $1.47(1.4 ; 1.5)$ \\
\hline Glycated hemoglobin (mg/dL) & & & 3516 & $51.1(5.0 ; 5.1)$ \\
\hline C-Peptide ${ }^{a}$ (ng/mL) & 3807 & $1.6(1.5 ; 1.6)$ & & \\
\hline \multicolumn{5}{|l|}{ Hemodynamic } \\
\hline Systolic arterial pressure $(\mathrm{mmHg})$ & 4291 & $117.4(116.9 ; 117.9)$ & 3593 & $121.0(120.6 ; 121.5)$ \\
\hline Diastolic arterial pressure $(\mathrm{mmHg})$ & 4291 & $73.5(73.2 ; 73.9)$ & 3593 & $75,3(75.0 ; 75.6)$ \\
\hline Heart rate (bpm) & 4291 & $74.5(74.1 ; 74.8)$ & 1565 & $70.7(70.1 ; 71.3)$ \\
\hline \multicolumn{5}{|l|}{ Behavioral } \\
\hline Prevalence of sedentary lifestyle & 4269 & $444.8(428.3 ; 461.2)$ & 3580 & $294.7(282.5 ; 307.0)$ \\
\hline
\end{tabular}

$\mu$ : arithmetic mean; ${ }^{\text {a }}$ : Geometric mean 
population according to the outcomes. C-Peptide was measured in 3807 subjects and the geometric mean was $1.6 \mathrm{ng} /$ $\mathrm{mL}(\mathrm{CI} 95 \% 1.5 ; 1.6)$. From 23 to 30 years, the mean total cholesterol increased from 155.9 to $190.6 \mathrm{mg} / \mathrm{dL}$, HDL from 55.5 to $58.7 \mathrm{mg} / \mathrm{dL}$, the geometric mean of triglycerides from 88.4 to $100.4 \mathrm{mg} / \mathrm{dL}$, and Hs-CRP from 2.0 to $1.47 \mathrm{mg} / \mathrm{dL}$. Concerning the anthropometric measures, mean waist circumference increased from 78.2 to $84.7 \mathrm{~cm}$ and BMI from 23.6 to $26.8 \mathrm{~kg} / \mathrm{m}^{2}$. Systolic blood pressure increased from 117.4 to $121.0 \mathrm{mmHg}$ and diastolic from 73.5 to $70.7 \mathrm{mmHg}$.

At 23 years, in transversal analysis, C-Peptide was positively associated with waist circumference, BMI, glycaemia, total cholesterol, triglycerides, and Hs-CRP, whereas a negative association was observed with HDL. Longitudinally at 30 years, C-Peptide remained associated with waist circumference and BMI at 30. Concerning the metabolic risk factors, only triglycerides and

Table 2 Cardiovascular risk factors according to C-Peptide quartiles at 23 and 30 years old

\begin{tabular}{|c|c|c|c|c|c|}
\hline \multirow[t]{2}{*}{ Cardiovascular risk factors } & \multicolumn{4}{|l|}{ C-Peptide } & \multirow{2}{*}{$\begin{array}{l}{ }^{\mathrm{b}} \mathrm{p} \\
\text { Trend value }\end{array}$} \\
\hline & 1st quartile & 2nd quartile & 3rd quartile & 4th quartile & \\
\hline & \multicolumn{4}{|l|}{23 years } & \\
\hline & $n=968$ & $n=958$ & $n=1015$ & $n=865$ & \\
\hline \multicolumn{6}{|l|}{ Anthropometric } \\
\hline Waist circumference (cm) & $76.6(75.9 ; 91.0)$ & $77.3(76.7 ; 77.9)$ & $78.3(77.6 ; 78.9)$ & $80.8(79.9 ; 81.6)$ & $<0.001$ \\
\hline Body mass index & $22.7(22.5 ; 22.9)$ & $23,4(23.1 ; 23.6)$ & $23.7(23.4 ; 23.9)$ & $24.7(24.3 ; 25.1)$ & $<0.001$ \\
\hline \multicolumn{6}{|l|}{ Metabolic } \\
\hline Capillary glycaemia (mg/dL) & $92.1(91.4 ; 92.9)$ & $94.4(93.6 ; 95.2)$ & $97,9(96.9 ; 98.8)$ & $104.8(103.7 ; 106.0)$ & $<0.001$ \\
\hline Total cholesterol (mg/dL) & $155.0(152.2 ; 157.9)$ & $154.5(151.9 ; 157.2)$ & $156.3(153.4 ; 159.2)$ & $157.9(154.9 ; 161.0)$ & 0.094 \\
\hline HDL cholesterol (mg/dL) & $56,2(55.3 ; 57.0)$ & $55.6(54.8 ; 56.4)$ & $55.2(54.4 ; 56.0)$ & $54.9(54.1 ; 55.8)$ & 0.032 \\
\hline Triglycerides (mg/dL) ${ }^{a}$ & $76,5(74,1 ; 78,9)$ & $76,5(74,1 ; 90,7)$ & $96,3(93,2 ; 99,5)$ & $108,4(104,4 ; 112,6)$ & $<0.001$ \\
\hline C-reactive protein $(\mathrm{mg} / \mathrm{dL})^{a}$ & $1,0(1,06 ; 1,08)$ & $1,0(1,06 ; 1,17)$ & $1,3(1,20 ; 1,39)$ & $1,4(1.3 ; 1.5)$ & $<0.001$ \\
\hline \multicolumn{6}{|l|}{ Hemodynamic } \\
\hline Systolic arterial pressure (mmHg) & $118.2(117.2 ; 119.2)$ & $116.7(115.8 ; 117.6)$ & $116.7(115.7 ; 117.6)$ & $117.5(116.6 ; 118.6)$ & 0.356 \\
\hline Diastolic arterial pressure (mmHg) & $73.9(73.2 ; 74.7)$ & $72.6(71.9 ; 73.3)$ & $72,9(72.2 ; 73.6)$ & $73.9(73.1 ; 74.6)$ & 0.765 \\
\hline \multirow[t]{3}{*}{ Heart rate (bpm) } & $73.0(72.2 ; 74.0)$ & $73.3(72.6 ; 74.0)$ & $75.9(75.2 ; 76.7)$ & $76.30(75.4 ; 77.0)$ & $<0.001$ \\
\hline & \multicolumn{4}{|l|}{30 years } & \\
\hline & $n=966$ & $n=955$ & $n=1006$ & $n=857$ & \\
\hline \multicolumn{6}{|l|}{ Anthropometric } \\
\hline Waist circumference $(\mathrm{cm})$ & $83.0(82.1 ; 83.7)$ & $84.2(83.4 ; 85.1)$ & $85.0(84.1 ; 86.0)$ & $87.7(86.6 ; 88.8)$ & $<0.001$ \\
\hline Body mass index & $25.8(25.4 ; 26.1)$ & $26.6(26.2 ; 27.0)$ & $27.1(26.7 ; 27.5)$ & $28.3(27.8 ; 28.8)$ & $<0.001$ \\
\hline \multicolumn{6}{|l|}{ Metabolic } \\
\hline Serum glycaemia (mg/dL) & $88.3(87.2 ; 89.4)$ & $87.3(86.2 ; 88.3)$ & $87.9(86.8 ; 88.9)$ & $88.5(87.2 ; 89.8)$ & 0.702 \\
\hline Total cholesterol (mg/dL) & 189.9 (187.3; 192.6) & $190.7(188.1 ; 193.3)$ & $191.0(188.4 ; 193.5)$ & $192.1(189.3 ; 194.9)$ & 0.084 \\
\hline HDL cholesterol (mg/dL) & $59.1(58.1 ; 60.0)$ & $58.8(57.8 ; 59.7)$ & $58.5(57.5 ; 59.4)$ & $58.6(57.5 ; 59.7)$ & 0.223 \\
\hline LDL cholesterol (mg/dL) & $109.4(107.3 ; 111.6)$ & $109.3(107.3 ; 111.4)$ & 109.7 (107.6; 111.8) & $110.3(108.1 ; 112.4)$ & 0.161 \\
\hline Triglycerides (mg/dL) ${ }^{a}$ & $94.5(91.0 ; 98.1)$ & $100.5(96.6 ; 104.6)$ & $101.9(97.9 ; 105.9)$ & $105.4(101.0 ; 111.0)$ & $<0.001$ \\
\hline C-reactive protein $(\mathrm{mg} / \mathrm{dL})^{a}$ & $1.17(1.07 ; 1.29)$ & $1.43(1.31 ; 1.57)$ & $1.64(1.50 ; 1.79)$ & $1.83(1.66 ; 2.00)$ & $<0.001$ \\
\hline Glycated hemoglobin (\%) & $5.06(5.03 ; 5.09)$ & $5.10(5.07 ; 5.14)$ & $5.11(5.08 ; 5.15)$ & $5.10(5.06 ; 5.14)$ & 0.087 \\
\hline \multicolumn{6}{|l|}{ Hemodynamic } \\
\hline Systolic arterial pressure (mmHg) & $122.0(121.0 ; 122.8)$ & $120.4(119.5 ; 121.4)$ & $121.7(120.0 ; 121.6)$ & $121.1(120.0 ; 122.2)$ & 0.215 \\
\hline Diastolic arterial pressure (mmHg) & $75.1(74.17 ; 75.8)$ & $74.8(74.2 ; 76.1)$ & $75.4(74.8 ; 76.0)$ & $76.4(75.6 ; 77.14)$ & 0.003 \\
\hline Heart rate (bpm) & $69.7(68.5 ; 70.9)$ & $70.5(69.3 ; 71.7)$ & $72.1(69.8 ; 72.5)$ & $71.2(70.0 ; 72.5)$ & 0.014 \\
\hline
\end{tabular}


$\mathrm{Hs}-\mathrm{CRP}$ at 30 years were associated with C-Peptide. At 23 and 30 years, only diastolic blood pressure was associated with C-Peptide, but this association did not show a linear pattern (Table 2).

Considering that the independent variable of positive family history for myocardial infarction was not significant in any of the multivariate stages used in the analysis $(\mathrm{p}=0.56)$, it was thus excluded from participation in subsequent level adjustments. Table 3 shows that, even after adjusting for confounding factors, C-Peptide remained associated with waist circumference and BMI at 23 and 30 years of age. Among the metabolic variables at 23 years, C-Peptide was positively associated with glycaemia, triglycerides, and Hs-CRP and negatively with
HDL cholesterol. In the longitudinal analysis at 30 years, C-Peptide was positively associated with glycated hemoglobin, triglycerides, and HS-CRP, and negatively with HDL cholesterol. Regarding hemodynamic variables, C-Peptide was not associated with systolic blood pressure, whereas diastolic blood pressure at 30 years was higher among those subjects in the upper quartile of C-Peptide.

\section{Discussion}

In the present study, the cross-sectional analysis at 23 years showed that C-Peptide was positively associated with waist circumference, BMI, glycaemia, triglycerides, and Creactive protein, whereas the association with

Table 3 Multivariate regression of cardiovascular risk factors and C-Peptide at 23 and 30 years old ${ }^{a}$

\begin{tabular}{|c|c|c|c|c|}
\hline \multirow[t]{3}{*}{ Cardiovascular risk factors } & 1st quartile & 2nd quartile & 3rd quartile & 4th quartile \\
\hline & $\mu(\mathrm{C} 195 \%)$ & $\beta(C \mid 95 \%)$ & $\beta(C 195 \%)$ & $\beta(C \mid 95 \%)$ \\
\hline & 23 years & & & \\
\hline \multicolumn{5}{|l|}{ Anthropometric } \\
\hline \multirow[t]{2}{*}{ Waist circumference $(\mathrm{cm})$} & Reference & $0.88(-0.46 ; 2.22)$ & $1.78(0.41 ; 3.15)$ & $4.90(3.45 ; 6.36)$ \\
\hline & Reference & $0.49(-0.38 ; 1.02)$ & $0.97(0.44 ; 1.52)$ & $2.15(1.57 ; 2.72)$ \\
\hline \multicolumn{5}{|l|}{ Metabolic } \\
\hline Serum glycaemia (mg/dL) & Reference & $2.58(0.67 ; 4.50)$ & $5.55(3.60 ; 7.49)$ & $11.19(9.80 ; 13.94)$ \\
\hline Total cholesterol (mg/dL) & Reference & $-0.38(-5.04 ; 4.28)$ & $0.95(-3.79 ; 5.70)$ & $1.76(-3.28 ; 6.80)$ \\
\hline HDL cholesterol (mg/dL) & Reference & $-2.12(-3.80 ;-0.44)$ & $-2.33(-4.04 ;-0.61)$ & $-2.10(-3.93 ;-0.29)$ \\
\hline Triglycerides (mg/dL) & Reference & $1.12(1.05 ; 1.20)$ & $1.19(1.05 ; 1.20)$ & $1.28(1.19 ; 1.38)$ \\
\hline C-reactive protein (mg/dL) & Reference & $0.94(0.81 ; 1.10)$ & $1.26(1.08 ; 1.47)$ & $1.42(1.20 ; 1.67)$ \\
\hline \multicolumn{5}{|l|}{ Hemodynamic } \\
\hline Systolic pressure (mmHg) & Reference & $-1.32(-3.39 ; 0.75)$ & $-1.93(-4.05 ; 0.18)$ & $-0.25(-2.48 ; 2.01)$ \\
\hline \multirow[t]{2}{*}{ Diastolic pressure (mmHg) } & Reference & $-1.88(-3.43 ;-0.32)$ & $-1.93(-3.52 ;-0.35)$ & $-0.20(-1.88 ; 1.47)$ \\
\hline & 30 years & & & \\
\hline \multicolumn{5}{|l|}{ Anthropometric } \\
\hline Waist circumference $(\mathrm{cm})$ & Reference & $1.0(-0.39 ; 2.41)$ & $1,74(0.30 ; 3.17)$ & $4.18(2.65 ; 5.70)$ \\
\hline Body mass index & Reference & $0.75(0.15 ; 1.34)$ & $1.26(0.65 ; 1.88)$ & $2.26(1.61 ; 2.91)$ \\
\hline \multicolumn{5}{|l|}{ Metabolic } \\
\hline Serum glycaemia (mg/dL) & Reference & $-1.28(-3.18 ; 0.62)$ & $-0.39(-2.33 ; 1.55)$ & $-0.66(-2.72 ; 1.40)$ \\
\hline Glycated hemoglobin (\%) & Reference & $0.06(0.01 ; 0.12)$ & $0.07(0.02 ; 0.13)$ & $0.07(0.01 ; 0.14)$ \\
\hline Total cholesterol (mg/dL) & Reference & $-0.62(-4.93 ; 3.68)$ & $-0.69(-5.11 ; 3.71)$ & $-2.20(-6.88 ; 2.47)$ \\
\hline HDL cholesterol (mg/dL) & Reference & $-0.79(-2.42 ; 0.84)$ & $-1.30(-2.97 ; 0.36)$ & $-1.82(-3.59 ;-0.05)$ \\
\hline LDL cholesterol (mg/dL) & Reference & $-0.76(-4.23 ; 2.70)$ & $-0.68(-4.23 ; 2.86)$ & $-0.98(-4.75 ; 2.78)$ \\
\hline Triglycerides (mg/dL) & Reference & $1,06(0,99 ; 1,13)$ & $1,07(1,0 ; 1,14)$ & $1,06(0,99 ; 1,14)$ \\
\hline C-reactive protein (mg/dL) & Reference & $1,23(1,06 ; 1,42)$ & $1,51(1,30 ; 1,75)$ & $1,54(1,32 ; 1,80)$ \\
\hline \multicolumn{5}{|l|}{ Hemodynamic } \\
\hline Systolic pressure $(\mathrm{mmHg})$ & Reference & $-0.96(-2.54 ; 1.62)$ & $-0.25(-1.87 ; 1.36)$ & $-0.03(-1.75 ; 1.68)$ \\
\hline Diastolic pressure (mmHg) & Reference & $-0.44(-1.53 ; 0.65)$ & $0.45(-0.66 ; 1.56)$ & $1.12(-0.06 ; 2.30)$ \\
\hline
\end{tabular}

$\mu$ geometric mean

adjusted for: time of fasting, physical activity practice per week (minutes), family income, mother's skin color, birthweight, rapid growth between 2 and 4 years old, smoking at 23 years, alcohol consumption, family history of dyslipidemia, arterial hypertension and stroke, myocardial infarction

Values presented in bold present statistical significance 
HDL cholesterol was in the opposite direction. In the longitudinal analysis, C-Peptide remained positively associated with waist circumference, BMI, glycated hemoglobin, triglycerides, and C-reactive protein and negatively with HDL cholesterol. The direction of the association with diastolic blood pressure changed, i.e., at 23 years' diastolic blood pressure was higher among those in the first quartile of C-Peptide whereas the opposite was observed at 30 years.

Studies on the effect of C-Peptide on glycaemia have yielded conflicting evidence. Whereas Hoogwerf et al. found no association [24], Oskarsson et al. reported that C-Peptide enhances insulin-induced hypoglycemia among diabetic patients [25]. Nordquist et al. showed that C-Peptide infusion in patients with type-I diabetes improves glucose use by about $25 \%$ [26]. In the present study, C-Peptide was positively associated with glycaemia at 23 years, but no association was observed in the longitudinal analysis at 30 years. That may be due to the increase in insulin resistance, which would be the result of the rise in the prevalence of overweight - from 28.3 to $57.6 \%$ - from 23 to 30 years [27], increasing the peripheral resistance to insulin, which, along with hyperinsulinemia, would result in a temporary reduction in glycemic status.

On the other hand, the findings of the associations with abdominal circumference and body mass index are based on the understanding that increased visceral fat contributes to insulin resistance and pro-inflammatory adipokine production by means of monocyte attraction protein (MCP-1) in addition to its greater performance on catecholaminergic receptors and lower performance on insulin receptors, which favors a greater release of free fatty acids and hypertriglyceridemia, which in turn favors the lipotoxicity phenomenon, which was transversely identified and remained associated longitudinally at 30 years $[28,29]$.

C-Peptide was associated with triglycerides at 23 and 30 years. Although they cannot be considered a marker of atherogenic risk by themselves, triglycerides in association with other components such as obesity, diabetes, or hypertension are a marker of cardiovascular risk [30]. In addition to this condition, the negative relation with HDL cholesterol at 23 and 30 years old stands out. Suggesting that C-Peptide is associated with metabolic factors related to cardiovascular risk. C-reactive protein, a marker of systemic inflammatory process, was considered a cardiovascular risk factor [31-34]. Danesh (2004), in a meta-analysis of observational studies, observed that those in the highest tercile of $\mathrm{C}$-reactive protein were at higher risk of cardiovascular events (OR 1.45; CI95\% 1.25-1.68) [35]. However, a Mendelian randomization study showed that Hs-CRP was not independently associated with cardiovascular risk and that it could be a marker of risk [36]. In the present study, C-Peptide remained associated with $\mathrm{Hs}-\mathrm{CRP}$ at 23 and 30 years old, which suggests that C-Peptide is associated with the systemic inflammatory process.

Diastolic blood pressure was positively associated with C-Peptide at 23 years, but, unlike Chen and Every [37, 38] systolic blood pressure was not associated with C-Peptide. Although it accepts the association between insulin resistance and the condition of hypertension due to favoring the conditions of vasoconstriction, greater renal resorption of sodium and increased production of angiotensin II at the level of visceral fat. Which in turn, leads to less production of oxide nitric acid and hypertrophy in the mucosal mean of vessels by the action of hyperinsulinemia, our findings did not observe association with the

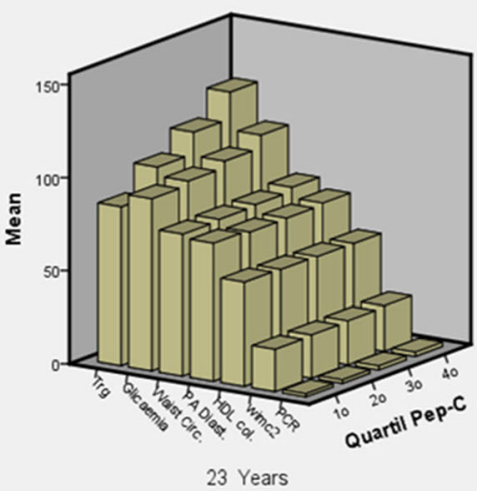

23 Years

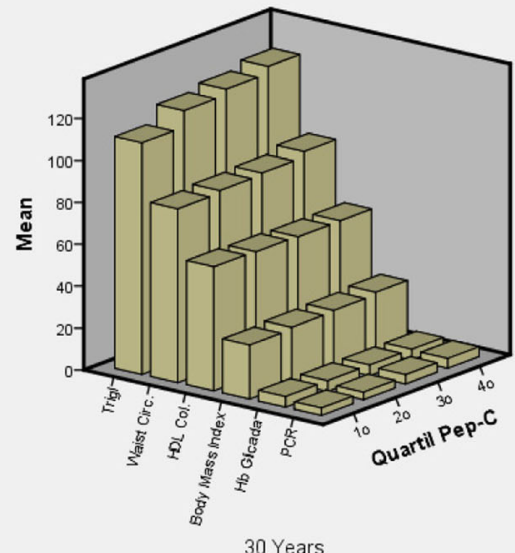

30 Years

Fig. 1 Cardiovascular risk components associated with Pep-C at 23 and 30 years 
tensional state and the levels of the pep-C quartiles at 23 or 30 years.

The majority prevalence of diabetes in developing countries, stay in the 45 to 64 -year age range, in contrast, with developed countries ( $>64$ years of age) [39]. Our findings are in line with the epidemiological profile indicated, since the associates found to be pre-findings point to a condition of insulin resistance associated with conditions of cardiometabolic risk already present at $23^{\mathrm{a}}$ and is maintained longitudinally at the end of the $3^{\text {a }}$ decade of life. A strength of this study is its population-based design and the large proportion of the sample successfully followed, which minimized the likelihood of selection bias. Among the limitations, it could be pointed that the biochemical tests were carried out in non-fasting samples. On the other hand, more recent evidence indicates that casual exams allow better risk estimate [40] and, furthermore, the analyses were adjusted for time of fasting.

\section{Conclusion}

In a population that has been prospectively followed since birth, we observed a positive relationship between C-Peptide and obesity indicators such as waist circumference and BMI at 23 years and 30 years of age (as shown in Fig. 1). C-Peptide was also associated with the systemic inflammatory process and the higher level of metabolic cardiovascular risk factors.

\section{Abbreviations}

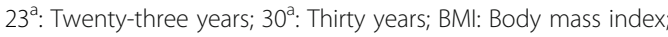
$\mathrm{cm}$ : Centimeters; C-Peptide: Insulin-binding peptide; $\mathrm{HbA}_{1}$ : Glycated hemoglobin; HDL: High-density lipoprotein - HDL cholesterol; HR: Hazard ratio; HS-CRP: High-sensitivity C-reactive protein; IPAQ: International physical activity questionnaire; kg: Kilograms; LDL: Low-density lipoprotein - LDL cholesterol; MCP-1: Monocyte attraction protein; mg/dL: Milligrams per deciliter; mm: Millimeters; mmHg: Millimeters of mercury; ng/mL: Nanogram per milliliter; RR: Relative risk; tPA: Tissue plasminogen activator; $\mu$ : Geometric mean
}

\section{Acknowledgements}

The Wellcame Trust and ABRASCO for the collaboration and support of the creation of the Pelotas Cohort and publication assistance.

\section{Funding}

Institutional PhD Program of the Coordination of Improvement of Higher Education Personnel- CAPES/MEC; Brasil, through technical cooperation between UFPel / UFES, developed by the Graduate Program in Epidemiology of UFPel.

\section{Availability of data and materials}

The dataset will be available at the Graduate Program in Epidemiology UFPel Center of epidemiologic Research.

Rua Marechal Deodoro, $1160-3^{\circ}$ Andar

Centro - Pelotas, RS; Brazil

Postal code: 96020-220 - PO Box 464

Tel / fax + 55 (53) 3284-1300

http://epidemio-ufpel.org.br/site/content/contato/index.php

It's use for analysis will be available after evaluation of the purpose of the request and condition of acceptance the reliability of such data.

\section{Authors' contributions}

RLMA - designed the study, performed the statistical analysis and prepared the initial manuscript. DPG - Interpreted the analyzed results and revised the manuscript. 100 - Interpreted the results and revised and revised the manuscript. BLH - Contributed to the design of the study, supervised the statistical analysis, interpreted the results analyzed and revised the manuscript. All authors have approved the final version to be submitted and agree to be responsible authors for the aspects of the work in order to ensure that issues related to the accuracy or completeness of any part of the work are properly investigated and resolved.

\section{Ethics approval and consent to participate}

Approval by the Ethics Committee off FEDERAL UNIVERSITY OF PELOTAS MEDICAL SCHOOL, RESEARCH ETHICS COMMITTEE by DOC N ${ }^{\circ}$ OF. 16/12. All the participants provided signed the free and informed participation agreement.

\section{Consent for publication}

Not applicable.

\section{Competing interests}

The authors declare that they have no competing interests.

\section{Publisher's Note}

Springer Nature remains neutral with regard to jurisdictional claims in published maps and institutional affiliations.

\section{Author details}

'University Hospital Cassiano Antônio de Moraes (HUCAM) of the Federal, University of Espírito Santo (UFES), Vitória-ES, Brazil. ${ }^{2}$ Post-Graduate Program in Epidemiology, Federal University of Pelotas (UFPel), Pelotas-RS, Brazil. ${ }^{3}$ Vitória, Brazil.

Received: 18 December 2017 Accepted: 17 October 2018

Published online: 06 November 2018

References

1. Mendis S, Puska P, Norrving B, editors. Global Atlas on Cardiovascular Disease Prevention and Control. Geneva: World Health Organization; 2011. ISBN 978924156437 3. http://www.who.int/cardiovascular_diseases/ publications/atlas_cvd/en/

2. Global action plan for the prevention and control of noncommunicable diseases 2013-2020. 1. Chronic diseases. 2. Cardiovascular diseases. 3. Neoplasms. 4. Respiratory tract diseases. 5. Diabetes mellitus. 6. Health planning. 7. International cooperation. I.World Health Organization. ISBN 978 924 1506236. http://apps.who.int/iris/bitstream/10665/94384/1/ 9789241506236_eng.pdf. Accessed 25 Oct 2018.

3. Piepoli MF, Hoes AW, Agewall S, Albus C, Brotons C, Catapano AL, et al. 2016 European Guidelines on cardiovascular disease prevention in clinical practice. Eur Heart J. 2016:37(29):2315. https://doi.org/10.1093/eurhearti/ ehw106.

4. Ordunez P, Prieto-Lara E, Pinheiro Gawryszewski V, Hennis AJM, Cooper RS. Premature Mortality from Cardiovascular Disease in the Americas - Will the Goal of a Decline of "25\% by 2025" be Met? PLoS One. 2015;10(10): e0141685. https://doi.org/10.1371/journal.pone.0141685.

5. Younk LM, Lamos EM, Davis SN. The cardiovascular effects of insulin. Expert Opin Drug Saf. 2014;13(7):955-66. https://doi.org/10.1517/14740338.2014. 919256 Epub 2014 Jun 5. Review. PubMed PMID: 24899093. http://www. tandfonline.com/doi/abs/10.1517/14740338.2014.919256?journalCode= ieds20.

6. Li Y, Li Y Y, Meng L, Zheng L. Association between serum C-Peptide as a risk factor for cardiovascular disease and high-density lipoprotein cholesterol levels in nondiabetic individuals. PLoS One. 2015;10(1):e112281. https://doi. org/10.1371/journal.pone.0112281 eCollection 2015. PubMed PMID: 25559358; PubMed Central PMCID: PMC4283961. http://journals.plos.org/ plosone/article?id=10.1371/journal.pone.0112281.

7. Min JY, Min KB. Serum C-Peptide levels and risk of death among adults without diabetes mellitus. CMAJ. 2013;185(9):E402-8. https://doi.org/10. 1503/cmaj.121950 Epub 2013 Apr 15. PubMed PMID: 23589428; PubMed Central PMCID: PMC3680586. http://www.cmaj.ca/content/185/9/E402.long.

8. Steiner DF, Cunningham D, Spigelman L, et al. Insulin biosynthesis: evidence for a precursor. Science. 1967;157(3789):697-700 http://science.sciencemag. org/content/157/3789/697.long. 
9. Hirai FE, Moss SE, Klein BE, Klein R. Relationship of glycemic control, exogenous insulin, and C-Peptide levels to ischemic heart disease mortality over a 16-year period in people with older-onset diabetes: the Wisconsin Epidemiologic Study of Diabetic Retinopathy (WESDR). Diabetes Care. 2008; 31(3):493-7 https://www.ncbi.nlm.nih.gov/pmc/articles/PMC2773445/.

10. Wahren J, Shafqat J, Johansson J, Chibalin A, Ekberg K, Jornvall H. Molecular and cellular effects of C-Peptide- new perspectives on an old peptide. Exp Diabesity Res. 2004;5(1):15-23 https://www.ncbi.n/m.nih.gov/pmc/articles/ PMC2892072/pdf/125_2010_Article1736.pdf.

11. Walcher D, Babiak C, Poletek P, Rosenkranz S, Bach H, Betz S, Durst R, Grüb M, Hombach V, Strong J, Marx N. C-Peptide induces vascular smooth muscle cell proliferation: involvement of SRC-kinase, phosphatidylinositol 3kinase, and extracellular signal-regulated kinase 1/2. Circ Res. 2006;99(11): 1181-7 PubMed PMID: 17068290 http://circres.ahajournals.org/content/99/ 11/1181.long.

12. Marx N, Walcher D. C-Peptide and Atherogenesis: C-Peptide as a Mediator of Lesion Development in Patients with Type 2 Diabetes Mellitus? Exp Diabesity Res. 2008;2008:385108. https://doi.org/10.1155/2008/385108 5 pages. https://www.hindawi.com/journals/jdr/2008/385108/.

13. Cabrera de Leon A, Oliva Garcia JG, Marcelino Rodriguez I, Almeida Gonzalez D, Aleman Sanchez JJ, Brito Diaz B, et al. C-Peptide as a risk factor of coronary artery disease in the general population. Diab Vasc Dis Res. 2015;12(3):199-207 http://dvr.sagepub.com/content/12/3/199.long.

14. Marx N, Silbernagel G, Brandenburg V, Burgmaier M, Kleber ME, Grammer $T B$, et al. C-Peptide levels are associated with mortality and cardiovascular mortality in patients undergoing angiography: the LURIC study. Diabetes Care. 2013;36(3):708-14 http://care.diabetesjournals.org/content/36/3/708.

15. Patel N, Taveira TH, Choudhary G, Whitlatch H, Wu WC. Fasting serum CPeptide levels predict cardiovascular and overall death in nondiabetic adults. J Am Heart Assoc. 2012;1(6):e003152. https://doi.org/10.1161/JAHA. 112.003152 PubMed PMID: 23316320; PubMed Central PMCID: PMC3540682 https://www.ncbi.nlm.nih.gov/pmc/articles/PMC3540682/.

16. Bo S, Gentile L, Castiglione A, Prandi V, Canil S, Ghigo E, et al. C-Peptide and the risk for incident complications and mortality in type 2 diabetic patients: a retrospective cohort study after a 14-year follow-up. Eur J Endocrinol. 2012;167(2):173-80 https://eje.bioscientifica.com/view/journals/eje/167/2/ 173.xml

17. Victora CG, Barros FC. Cohort Profile: The 1982 Pelotas (Brazil) Birth Cohort Study. Int J Epidemiol. 2006;35(2):237-42. https://doi.org/10.1093/ije/dyi290 First published online December 22, 2005. https://academic.oup.com/ije/ article/35/2/237/694731.

18. Horta BL, Gigante DP, Goncalves H, dos Santos Motta J, Loret de Mola C, Oliveira IO, et al. Cohort Profile Update: https://academic.oup.com/ije/ article/44/2/441/753028. Accessed 25 Oct 2018.

19. Lohman TG, Roche AF, Martorell R, editors. Anthropometric Standardization Reference Manual. Champaign: Human Kinetics Books; 1988. p. 5570.

20. C-Peptide Assay Specifications. The 1982 Pelotas (Brazil) Birth Cohort Study. Int J Epidemiol. 2015;44(2):441 Siemens Healthcare Diagnostics Products Ltd. Llanberis, Gwynedd LL 55 4EL United Kingdom. https://www.healthcare. siemens.com/clinical-specialities/diabetes/diabetes-related-assays/ clinicalsignificance.

21. Nazmi A, Oliveira IO, Horta BL, Gigante DP, Victora CG. Lifecourse socioeconomic trajectories and C-reactive protein levels in young adults: findings from a Brazilian birth cohort. Soc Sci Med. 2010;70(8):1229-36. https://doi.org/10.1016/j.socscimed.2009.12.014 PubMed PMID: 20137842; PubMed Central PMCID: PMC2877874. https://www.ncbi.nlm.nih.gov/pmc/ articles/PMC2877874/.

22. American Diabetes Association. (2) Classification and diagnosis of diabetes. Diabetes Care. 2015;38(Suppl):S8-S16. https://doi.org/10.2337/dc15-S005 Review. PubMed PMID: 25537714. http://care.diabetesjournals.org/content/ diacare/38/Supplement_1/S8.full.pdf.

23. Brasil. Ministério da Saúde. Secretaria de Atenção à Saúde. Departamento de Atenção Básica. Atenção ao pré-natal de baixo risco / Ministério da Saúde. Secretaria de Atenção à Saúde. Departamento de Atenção Básica. Brasília: Editora do Ministério da Saúde, 2012. 318 p.: il. - (Série A. Normas e Manuais Técnicos) (Cadernos de Atenção Básica, n 32) ISBN978-85-334 1936-0. http://bvsms.saude.gov.br/bvs/publicacoes/cadernos_atencao_ basica_32_prenatal.pdf

24. Andrade RLM, Gigante DP, de Oliveira IO, Horta BL. Conditions of gestation, childbirth and childhood associated with C-peptide in young adults in the 1982 Birth Cohort in Pelotas-RS; Brazil. BMC Cardiovasc Disord. 2017;17(1):
181. https://doi.org/10.1186/s12872-017-0613-3 PubMed PMID: 28693499; PubMed Central PMCID: PMC5504841.

25. Hoogwerf BJ, Bantle JP, Gaenslen HE, Greenberg BZ, Senske BJ, Francis R, Goetz FC. Infusion of synthetic human C-Peptide does not affect plasma glucose, sérum insulin, or plasma glucagon in healthy subjects. Metabolism. 1986;35(2):122-5 PubMed PMID: 3511350 http://www.sciencedirect.com/ science/article/pii/0026049586901113?via\%3Dihub.

26. Oskarsson P, Johansson BL, Adamson U, Lins PE. Effects of C-Peptide on insulin-induced hypoglycaemia and its counterregulatory responses in IDDM patients. Diabet Med. 1997;14(8):655-9 PubMed PMID: 9272591. https://onlinelibrary.wiley.com/doi/pdf/10.1002/\%28SICI\%2910969136\%28199708\%2914\%3A8\%3C655\%3A\%3AAID-DIA435\%3E3.0.CO\%3B2-G.

27. Nordquist $L$, Johansson M. Proinsulin C-Peptide: friend or foe in thedevelopment of diabetes-associated complications? Vasc Health Risk Manag. 2008;4(6):1283-8 Review. PubMed PMID: 19337542; PubMed Central PMCID: https://www.ncbi.nlm.nih.gov/pmc/articles/PMC2663462/pdf/NHRM4-1283.pdf.

28. Schaffer JE. Lipotoxicity: when tissues overeat. Curr Opin Lipidol. 2003;14(3): 281-7. Review. PubMed PMID: 12840659. https://doi.org/10.1097/01.mol. 0000073508.41685.7f.

29. Ertunc ME, Hotamisligil GS. Sinalização lipídica e lipotoxicidade em metaflammation: indicações para patogênese e tratamento da doença metabólica. J Lipid Res. 2016 dez; 57 (12): 2099-2114. Epub 2016 Jun 21. Review. PubMed PMID: 27330055; PubMed Central PMCID: PMC5321214

30. Lima NP, Horta BL, Motta JV d S, Valença MS, Oliveira V, dos Santos TV, Gigante DP, Barros FC. Evolução do excesso de peso e obesidade até a idade adulta, Pelotas, Rio Grande do Sul, Brasil, 1982-2012. Cad Saude Publica. 2015;31(9):2017-25. https://doi.org/10.1590/0102-311X00173814

31. Miller M, Stone NJ, Ballantyne C, Bittner V, Criqui MH, Ginsberg HN, Goldberg AC, Howard WJ, Jacobson MS, Kris-Etherton PM, Lennie TA, Levi M, Mazzone T, Pennathur S. American Heart Association Clinical Lipidology, Thrombosis, and Prevention Committee of the Council on Nutrition, Physical Activity, and Metabolism.; Council on Arteriosclerosis, Thrombosis and Vascular Biology.; Council on Cardiovascular Nursing.; Council on the Kidney in Cardiovascular Disease. Triglycerides and cardiovascular disease: a scientific statement from the American Heart Association. Circulation. 2011; 123(20):2292-333. https://doi.org/10.1161/CIR.0b013e3182160726 PubMed PMID: 21502576. http://circ.ahajournals.org/content/123/20/2292.

32. Harchaoui KE, Visser M, Kastelein JJ, Stroes E, Dallinga-Thie G. Triglycerides and Cardiovascular Risk. Curr Cardiol Rev. 2009;5(3):216-22. https://doi.org/ 10.2174/157340309788970315 https://www.ncbi.n/m.nih.gov/pmc/articles/ PMC2822144/pdf/CCR-5-216.pdf.

33. Galper BZ, Wang YC, Einstein AJ. Strategies for Primary Prevention of Coronary Heart Disease Based on Risk Stratification by the ACC/AHA Lipid Guidelines, ATPIII Guidelines, Coronary Calcium Scoring, and C-Reactive Protein, and a Global Treat-All Strategy: A Comparative--Effectiveness Modeling Study. PLoS One. 2015;10(9):e0138092. https://doi.org/10.1371/journal.pone.0138092 PubMed PMID: 26422204; PubMed Central PMCID: PMC4589241. https://www. ncbi.nlm.nih.gov/pmc/articles/PMC4589241/pdf/pone.0138092.pdf.

34. Kearney PM, Whelton M, Reynolds K, Muntner P, Whelton PK, He J. Global burden of hypertension: analysis of worldwide data. Lancet. 2005;365(9455): 217-23 https://www.sciencedirect.com/science/article/pii/ 0033062074900346

35. Ridker PM, Cook N. Clinical usefulness of very high and very low levels of Creactive protein across the full range of Framingham Risk Scores. Circulation. 2004;109(16):1955-9 PubMed PMID: 15051634 http://circ. ahajournals.org/content/109/16/1955.long.

36. Blaha MJ, Budoff MJ, DeFilippis AP, Blankstein R, Rivera JJ, Agatston A, et al. Associations between C-reactive protein, coronary artery calcium, and cardiovascular events: implications for the JUPITER population from MESA, a population-based cohort study. Lancet. 2011;378:684-92. https://doi.org/10. 1016/S0140-6736(11)60784-8.

37. Danesh J, Wheeler JG, Hirschfield GM, Eda S, Eiriksdottir G, Rumley A, Lowe GD, Pepys MB, Gudnason V. C-reactive protein and other circulating markers of inflammation in the prediction of coronary heart disease. N Engl J Med. 2004;350(14):1387-97 PubMed PMID: 15070788. http://www.nejm.org/doi/ full/10.1056/NEJMoa032804.

38. C Reactive Protein Coronary Heart Disease Genetics Collaboration (CCGC), Wensley F, Gao P, Burgess S, Kaptoge S, Di Angelantonio E, Shah T, Engert JC, Clarke R, Davey-Smith G, Nordestgaard BG, Saleheen D, Samani NJ, Sandhu M, Anand S, Pepys MB, Smeeth L, Whittaker J, Casas JP, Thompson 
SG, Hingorani AD, Danesh J. Association between C reactive protein and coronary heart disease: mendelian randomisation analysis based on individual participant data. BMJ. 2011;342:d548. https://doi.org/10.1136/bmj. d548 https://www.ncbi.nlm.nih.gov/pmc/articles/PMC3039696/.

39. Wild S, Roglic G, Green A, Sicree R, King H. Global prevalence of diabetes: estimates for the year 2000 and projections for 2030. Diabetes Care. 2004; 27(5):1047-53 PubMed PMID: 15111519. http://care.diabetesjournals.org/ content/27/5/1047.full-text.pdf.

40. Chen CH, Tsai ST, Chuang JH, Chang MS, Wang SP, Chou P. Populationbased study of insulin, C-Peptide, and blood pressure in Chinese with normal glucose tolerance. Am J Cardiol. 1995;76(8):585-8 http://www. sciencedirect.com/science/article/pii/S000291499980160X?via\%3Dihub.

Ready to submit your research? Choose BMC and benefit from:

- fast, convenient online submission

- thorough peer review by experienced researchers in your field

- rapid publication on acceptance

- support for research data, including large and complex data types

- gold Open Access which fosters wider collaboration and increased citations

- maximum visibility for your research: over $100 \mathrm{M}$ website views per year

At BMC, research is always in progress.

Learn more biomedcentral.com/submissions 